\title{
Operazioni di acquisizione massiva su componenti di matrice transalpina nell'architettura duecentesca del basso Lazio
}

\author{
Carlo Inglese \\ Emanuele Gallotta \\ Luca James Senatore \\ Guglielmo Villa
}

\section{Abstract}

II Duecento è per molti versi il secolo in cui Roma ritrova un ruolo preminente sullo scacchiere politico europeo e torna ad essere, di conseguenza, un polo culturale di prima grandezza. II fenomeno ha immediato riverbero anche nell'ambito regionale di riferimento, investendo i territori che componevano il Patrimonium Sancti Petri. Gli effetti non tardano a manifestarsi anche nello sviluppo della produzione artistica, grazie alla disponibilità di committenze culturalmente qualificate, che richiamano gli artisti più in vista del panorama italiano, accogliendo novità significative rispetto alla tradizione locale. Particolarmente rilevante è in questo contesto la diffusione di modelli strutturali e linguistici di derivazione francese, mutuati direttamente da esempi d'oltralpe o dalle più avanzate esperienze maturate nell'Italia centrale.

In questa prospettiva si inquadra il presente contributo volto alla realizzazione di un repertorio degli elementi architettonici di derivazione transalpina, che costituiscono il vocabolario del linguaggio architettonico duecentesco nel territorio a sud di Roma.
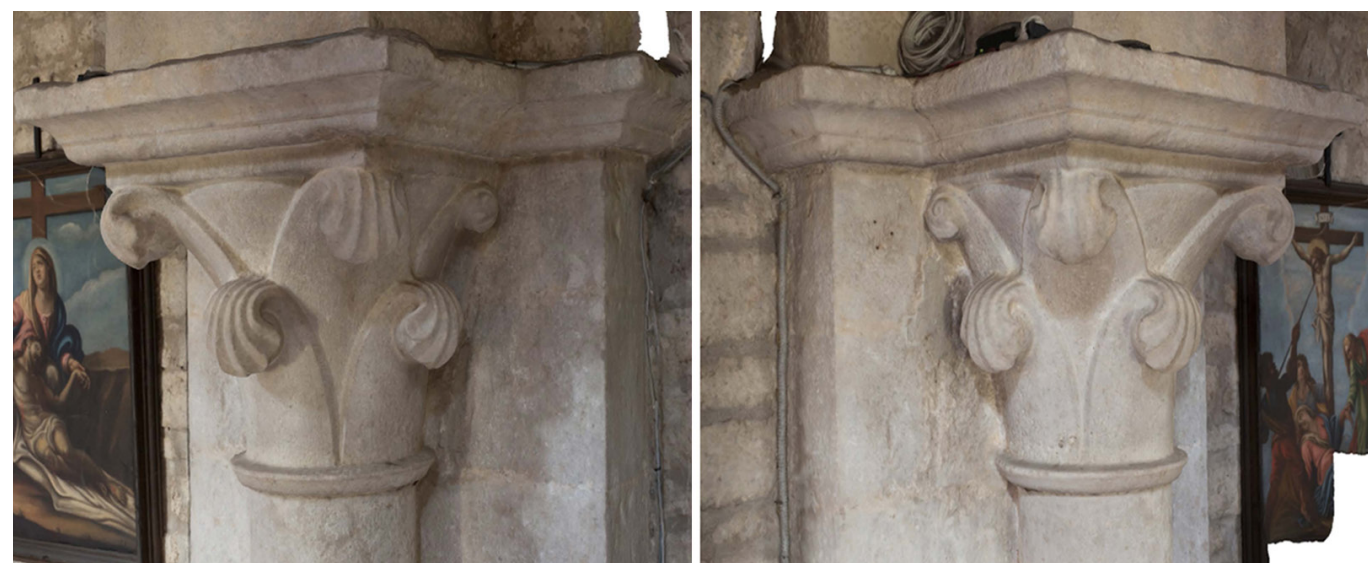


\section{Introduzione}

II Duecento è per molti versi il secolo in cui Roma ritrova un ruolo preminente sullo scacchiere politico europeo e torna ad essere, di conseguenza, un polo culturale di prima grandezza. Particolarmente significativa è in questo contesto la diffusione di modelli strutturali e linguistici di derivazione francese, mutuati direttamente da esempi transalpini o dalle più avanzate esperienze maturate nell'Italia centrale.

Un tema storiografico rilevante è costituito dall'architettura dell'ordine cistercense e dallo studio delle loro fabbriche, spesso di dimensioni notevoli, quali le abbazie di Fossanova e Casamari, con un nuovo modo di concepire l'architettura in termini di spazio, struttura e decorazione che si diffonde rapidamente a scala territoriale, in città come Anagni, Alatri e Ferentino.

In questa prospettiva si inquadra il presente contributo volto alla realizzazione di un repertorio degli elementi architettonici di derivazione francese, che costituiscono il vocabolario del linguaggio duecentesco nel territorio a sud di Roma.

L'indagine diretta delle fabbriche è stata finalizzata alla precisazione delle fasi costruttive, dalla quale si attendono dati rilevanti ai fini della loro lettura critica, ma anche a indagare aspetti più strettamente attinenti alla costruzione (tecniche, materiali, modalità di lavorazione e posa in opera) utili ad inquadrarne la realizzazione in un quadro più ampio di cultura materiale e a valutare eventuali apporti di maestranze estranee all'ambito locale.

Rilievi, osservazioni autoptiche e letture stratigrafiche degli alzati hanno permesso di comprendere più a fondo la cronologia delle fabbriche, spesso poco note o del tutto inedite sul piano scientifico e molto articolate nelle vicende costruttive. I confronti permettono, invece, di stabilire capisaldi temporali più solidi e precisi per gli sviluppi dell'architettura nell'ambito territoriale di riferimento.

Con questi presupposti sono stati individuati alcuni casi studio emblematici dal punto di vista delle caratteristiche formali degli elementi decorativi, capitelli gotici con elaborate soluzioni, o particolarmente importanti nel panorama architettonico del periodo studiato. Sono state, quindi, studiate l'abbazia di Fossanova, uno dei più importanti esempi di architettura cistercense in Italia, la cui costruzione, avviata negli anni '70 del XII secolo, proseguì ben oltre la sua consacrazione ( I 208); la chiesa di Santa Maria Maggiore a Ferentino, risalente alla seconda metà del Duecento; infine, la collegiata di Santa Maria Assunta ad Amaseno, consacrata nel I |77, la cui facies attuale è databile ai primi decenni del XIII secolo.

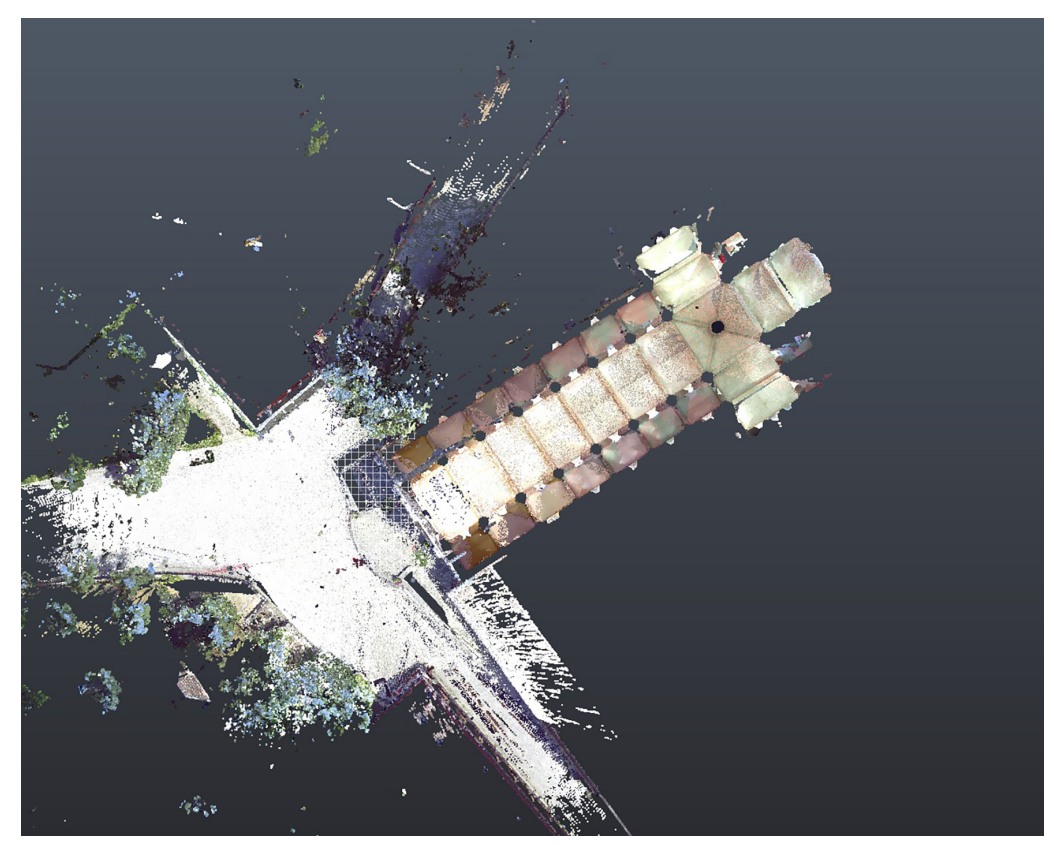




\section{Obiettivi della ricerca}

La ricerca si pone due obiettivi strettamente correlati: da un lato la rappresentazione, catalogazione e comparazione degli elementi architettonici e decorativi concentrando l'attenzione sulla decorazione plastica (capitelli, cornici, portali, finestre etc.) finalizzata all'individuazione delle relazioni storiche tra la cultura francese e le esperienza italiane; dall'altro la creazione di una piattaforma interattiva finalizzata alla divulgazione dei dai ricavati dallo studio, rivolta a un pubblico di tecnici e di non addetti ai lavori.

Questi obiettivi trovano nel momento del rilievo una fase chiave in grado di rispondere in maniera organica a entrambe le richieste, offrendo dati in grado di essere analizzati e resi divulgabili con operazioni ormai di consolidata valenza scientifica.

\section{II rilievo}

Le operazioni di rilievo integrato sono state condotte tenendo conto dei due obiettivi dello studio, il primo a carattere storico critico e il secondo di carattere divulgativo. Per questa ragione sono state condotte con una particolare attenzione alla qualità dei dati e ai loro successivi utilizzi.

Nello specifico per lo studio dei manufatti di si è proceduto integrando un rilievo $3 \mathrm{~d}$ scanner laser (fig. I), in grado di restituire la morfologia complessiva delle chiese studiate con un ottimo livello di dettaglio, con metodologie Structure from Motion (Fotogrammetria digitale) per gli apparati decorativi e i partiti architettonici.

II rilievo [I], quindi, è stato condotto integrando i dati provenienti da acquisizioni massive da 3d scanner laser per le parti generali con riprese fotografiche SfM, queste ultime dedicate a tutte quelle aree in quota, difficilmente raggiungibili se non con costose e non immediate opere provvisionali (fig. 2).
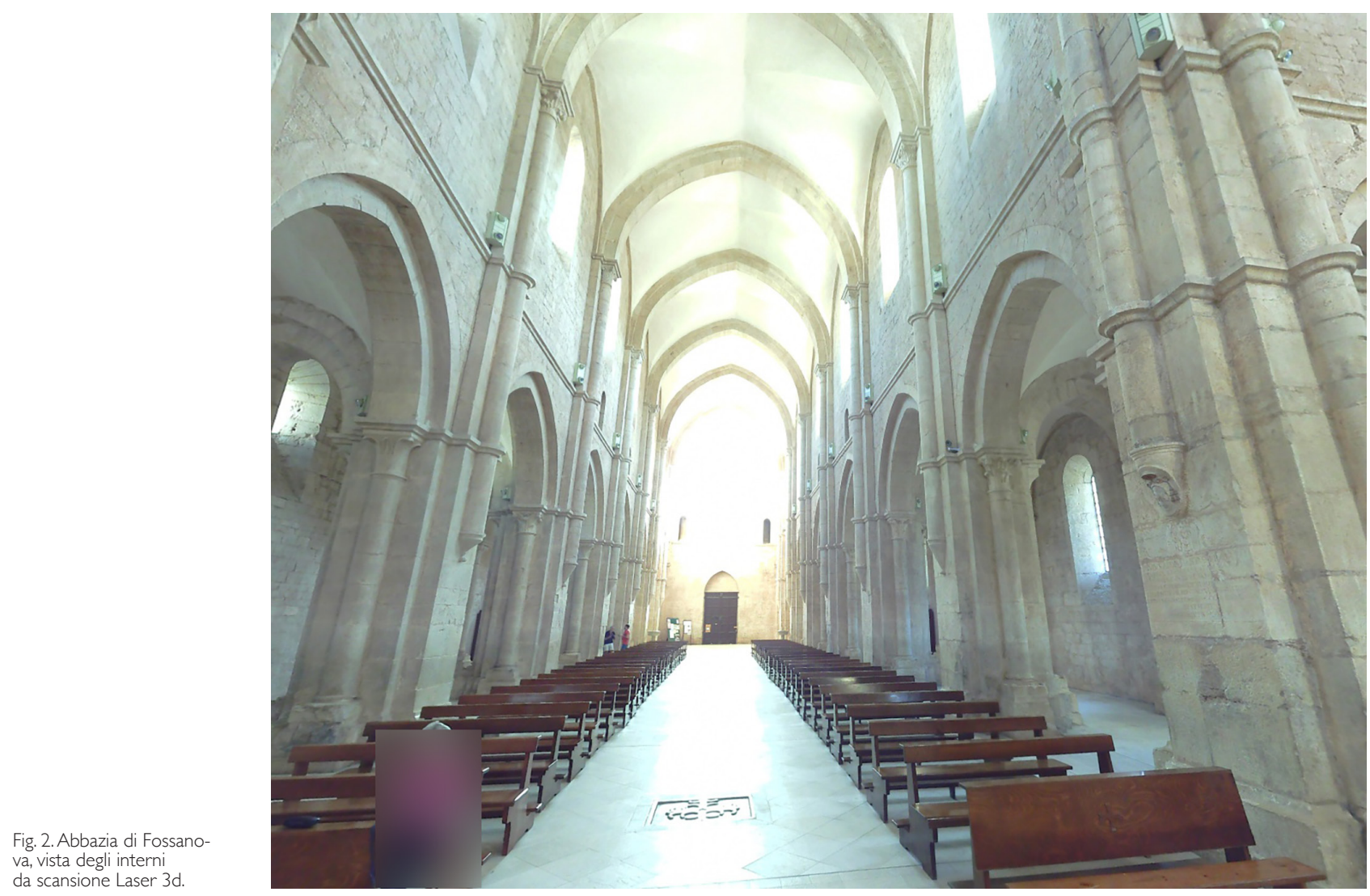
Le riprese fotografiche sono state effettuate con l'ausilio di un'asta telescopica alla cui sommità è stata posta la camera digitale [2] comandata in remoto per il controllo dei tempi di scatto ed esposizione. La fotocamera, utilizzata come strumento di acquisizione dati, permette una notevole versatilità nell'organizzazione della campagna di rilievo, consentendo, tra l'altro, la suddivisione dei vari elementi architettonici in diversi set fotografici. Ogni set fotografico, a sua volta, è stato strutturato considerando l'illuminazione naturale presente o prevedendo un sistema di illuminazione dedicato e impostando di volta in volta la modalità di ripresa fotografica ottimale.

I dati (xyz e rgb) così acquisiti sono stati elaborati in software dedicati producendo modelli digitali matematici che successivamente sono stati oggetto di trasformazione e modellazione in elaborati critici dedicati allo studio delle singole parti componenti il manufatto. Per quello che attiene in particolare agli elementi decorativi, è stata posta particolare attenzione nella realizzazione di modelli mesh ricavati da nuvola di punti che, una volta texturizzati impiegando i dati colore propri delle immagini fotografiche, hanno fornito una ottima base dati per la lettura storico stilistica delle componenti.

La restituzione degli elaborati ha interessato un gruppo interdisciplinare. II lavoro è attualmente in corso e la prima fase ha riguardato la produzione di modelli $2 \mathrm{D}$ dei principali elementi architettonici: a partire dalla nuvola di punti 3D sono state individuate sezioni orizzontali e verticali caratteristiche. Gli standard scientifici in ambito architettonico sono profondamente legati all'utilizzo di modelli 2D come strumento di documentazione critica e come collettore di informazione; a tale scopo, la creazione di un catalogo contenente i modelli 3D e 2D degli elementi architettonici rilevati, consentirebbe non solo una loro catalogazione attiva, cioè indagabile e interrogabile, ma anche uno studio comparativo attraverso la lettura di elementi compositivi ripetitivi o unici.

\section{Il caso dei capitelli}

Ciascun capitello analizzato è stato fotografato posizionando la camera ad altezze differenti con un numero variabile di scatti compreso tra i 30 (per i sostegni) e i 60 fotogrammi (per i capitelli) (fig. 3).

Sono state eseguite fotografie d'insieme di tutti gli oggetti analizzati e successivamente si è posta maggiore attenzione ai capitelli con fotografie dedicate garantendo la copertura di tutte le superfici.

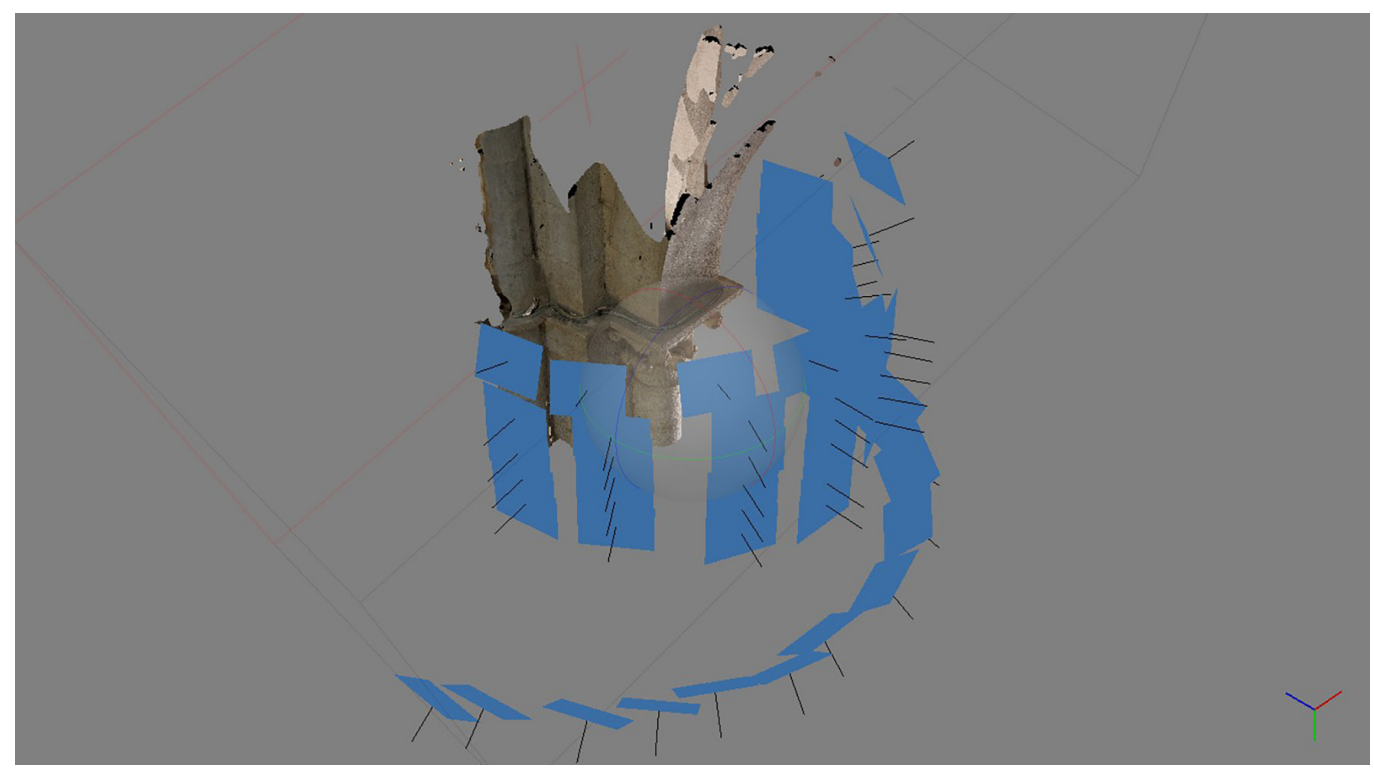


Il software per Sfm utilizzato (Photoscan) ha elaborato le immagini individuando la posizione relativa della macchina fotografica, ha generato la nuvola sparsa e successivamente quella densa che è stata trasformata in mesh e successivamente texturizzata.

Per quello che riguarda la misura sono stati utilizzati riferimenti metrici ricavati in situ su punti notevoli e, successivamente alla creazione del modello, questo è stato scalato per garantire modelli con scala di incertezza pari a I:20 (fig. 4).

Una volta realizzato il modello questo è stato ripulito e salvato in formato PDF 3D per essere facilmente visualizzabile all'interno di qualsiasi dispositivo fisso o mobile e posizionato in un repository online, al fine di rendere accessibile l'informazione anche in remoto utilizzando una connessione standard.

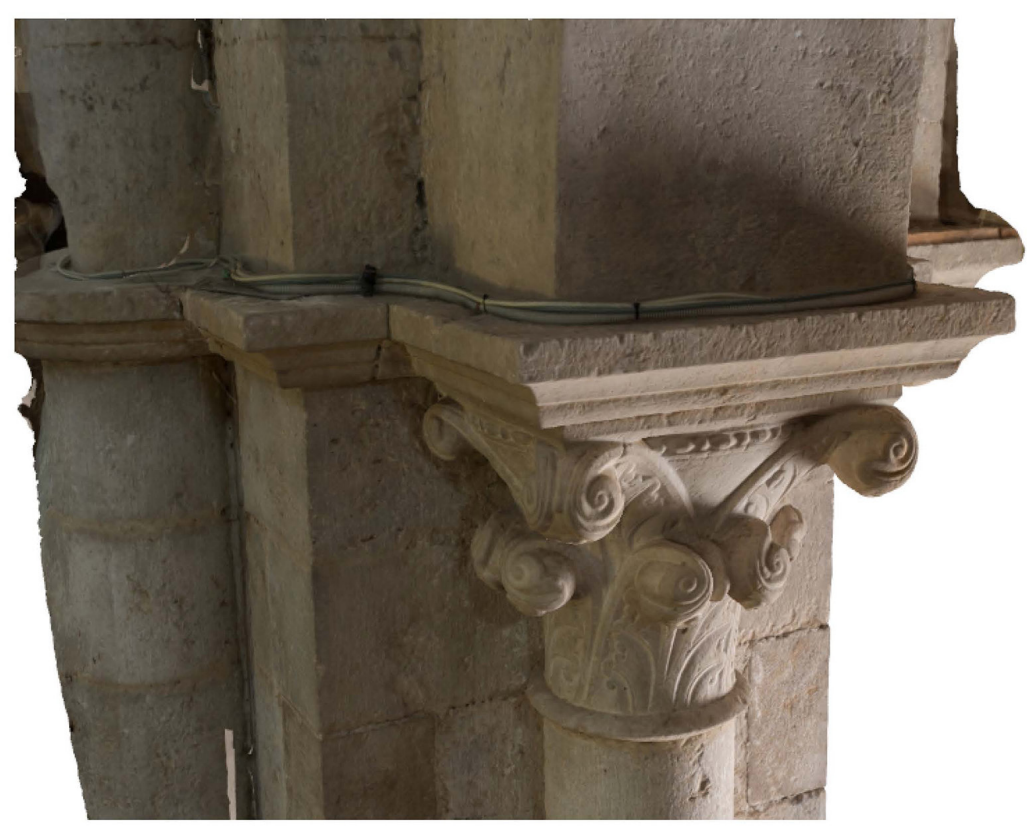

\section{La creazione di un catalogo digitale}

Attraverso l'utilizzo dei modelli realizzati per lo studio storico-critico, è stato possibile predisporre un catalogo digitale interattivo descrittivo dell'intero manufatto e delle sue porzioni caratterizzanti. In particolare, la modellazione Sfm e la creazione di modelli in grado di descrivere con un buon livello di dettaglio le superfici geometriche del manufatto ha permesso la sperimentazione di un nuovo modello di valorizzazione del bene culturale, che si è concentrato in particolare sulle componenti decorative.

Allo stesso tempo la procedura utilizzata ha permesso con una discreta velocità in fase di acquisizione, il raggiungimento di porzioni del manufatto che altrimenti non si sarebbero potute ottenere, garantendo una maggior qualità delle informazioni visualizzabili facendo uso della piattaforma.

Per la gestione dei dati è stato realizzato un prototipo di app open source offerto dalla piattaforma Mit.edu.

Facendo uso dell'applicazione predisposta per l'occasione il catalogo permette un buon livello di interazione tra oggetto e suo omologo digitale. Attraverso alcune pagine dedicate l'utilizzatore può navigare l'oggetto sia nelle sue componenti descrittive che in quelle storico critiche attraverso la visione di pagine dedicate o link a pagine web esterne.Vantaggio notevole di questo metodo di divulgazione è però da riscontrare per quello che riguarda la questione geometrico formale dell'insieme e delle parti. Attraverso moduli dedicati alla visualizzazione di file digitali (esterni o interni all'applicazione) i dati ricavati durante le fasi 
di acquisizione e modellazione possono essere facilmente navigati utilizzando gli usuali strumenti smart, tablet e telefoni in primis, offrendo all'utilizzatore nuove possibilità in termini di conoscenza e interazione con l'oggetto studiato.

Inoltre, sempre facendo uso di tools digitali dedicate, l'informazione, tradizionalmente presentata all'utilizzatore in maniera statica (testi e fotografia), oggi può essere navigata e interrogata in maniera interattiva con semplici passaggi che permettono quindi un livello di approfondimento personalizzato su di un'unica base dati geometricamente corretta.

Mediate un navigatore interattivo, ciascun utente, sia in situ che in remoto, ha la possibilità di approfondire la conoscenza del manufatto studiato con l'attivazione di schede tematiche in grado di restituire una serie di informazioni a carattere generale e di dettaglio. Attraverso l'utilizzo della medesima applicazione l'utente può selezionare i maggiori punti di interesse e averne non solo una descrizione puntuale e storicamente attendibile, ma, grazie all'integrazione dei dati ricavati dal rilievo e dalla modellazione, l'utente è in grado di visualizzare i modelli 3d sul monitor del proprio cellulare/tablet,

\section{L'app}

L'applicativo utilizzato per la visualizzazione delle schede tematiche e dei modelli $3 \mathrm{~d}$ è costituito da un prodotto opensource progettato e realizzato per le specifiche esigenze di visualizzazione ed esplorazione dei dati ricavati dallo studio, siano essi ottenuti direttamente dal rilievo o dall'elaborazione dei dati.

Dopo una prima pagina introduttiva (fig. 5), l'applicazione colloca le fabbriche oggetto di indagine all'interno di una mappa interattiva in grado di condurre l'utilizzatore nel luogo dove sono costruite (fig. 6).

Una volta giunti sul sito, dei link dedicati a pagine specificatamente progettate consentono all'utente di interrogare l'applicazione, così da ricavare informazioni sulle generalità dell'opera e sulle sue caratteristiche storico-artistiche (fig. 7).

Nello stesso tempo l'applicazione è in grado di fornire i link interattivi con le risorse del web e in particolare con siti contenenti articoli o prodotti della ricerca.

Volendo visualizzare in maniera interattiva il manufatto, viene offerta all'utente un'interfaccia che lo conduce a una serie di visualizzatori per nuvole di punti e modelli in formato PDF 3d dedicati alle porzioni di dettaglio (fig. 8).

Fig. 5. App: home page.

Fig. 6. App: screenshot di pagina
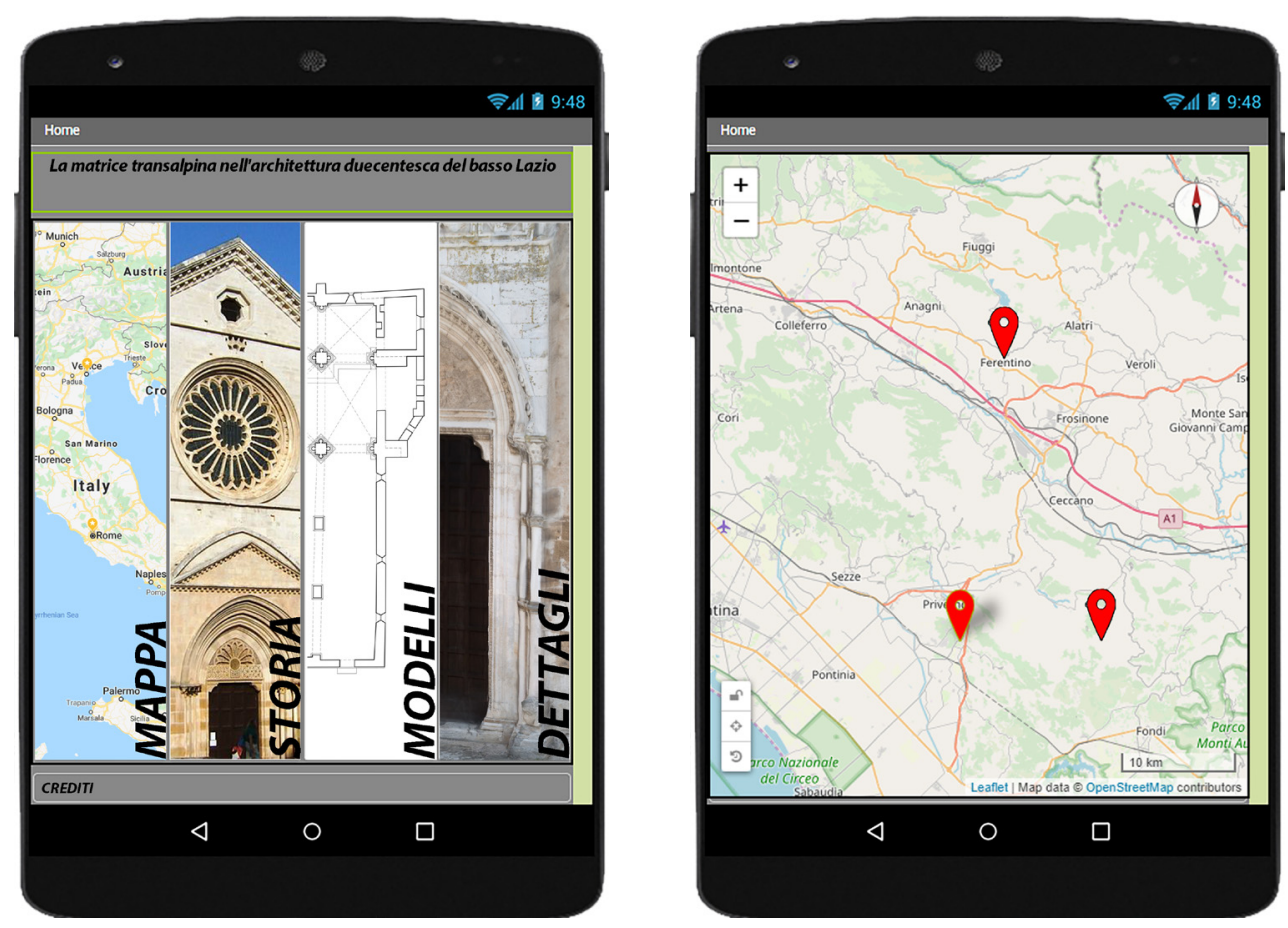
La navigazione è garantita da un navigatore dove sono portati i punti di interesse che, una volta individuati, permettono il caricamento dei dati relativi ai singoli modelli e alla loro esplorazione. Ulteriori tools in corso di sviluppo sono finalizzati alla verifica multilivello dei dati ricavati dal rilievo: mediante una sovrapposizione di dati in digitale è possibile ottenere dello stesso modello visioni differenti che lo rappresentano e lo identificano in varie modalità (geometrica semplificata, texturizzata, in falsi colori ecc.) con il quale l'utilizzatore può interagire per ottenere differenti tipologie di informazioni (fig. 9).

Fig. 7. App: screenshot di pagina.

Fig. 8. App: screenshot di pagina dedicata alla zzazione di modell in formato Pdf3d.
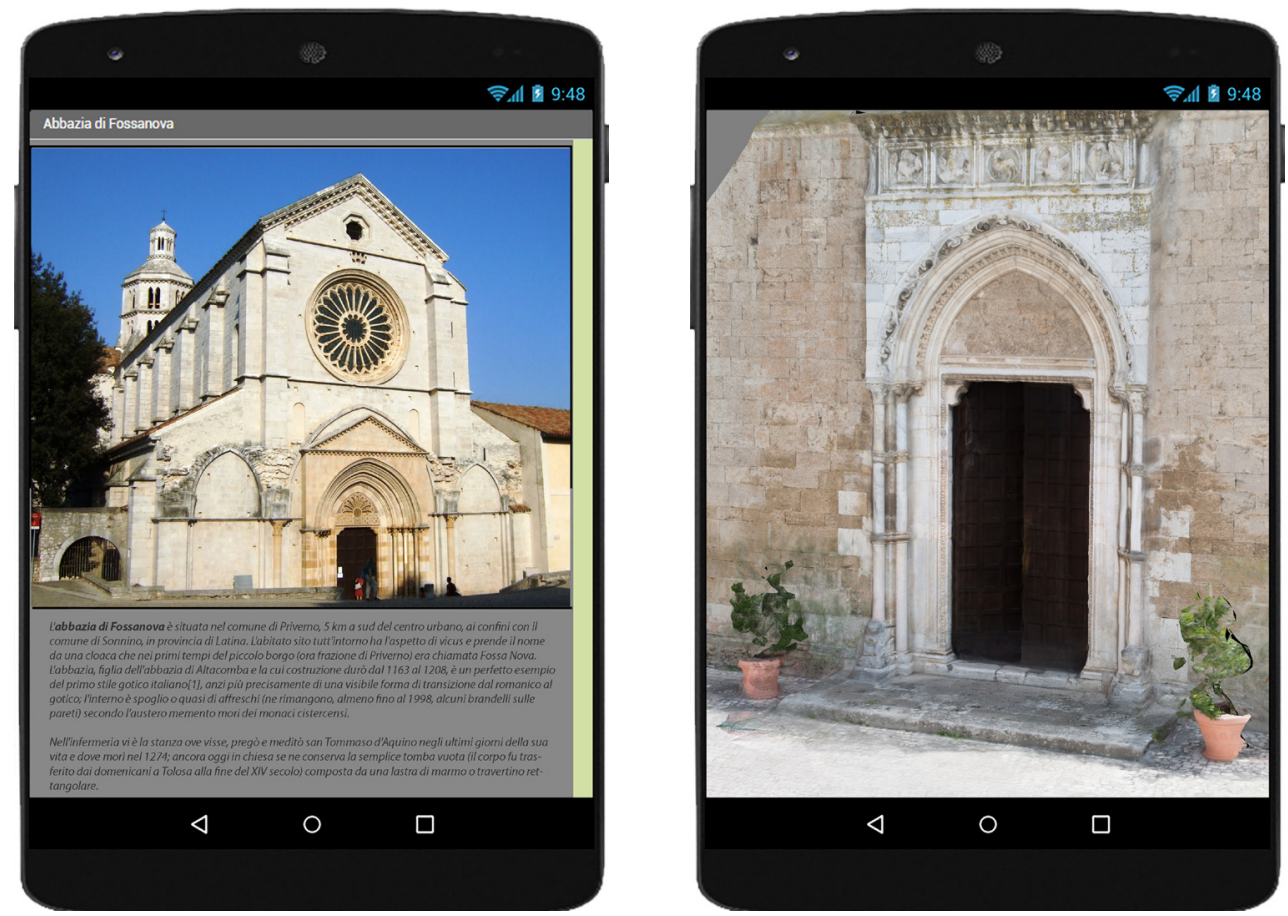

\section{Conclusioni}

II modello di studio qui proposto, pur garantendo la qualità scientifica dei dati, rappresenta un notevole passo in avanti nella divulgazione dei beni architettonici, facendo uso di strumenti di uso comune.

Attraverso la creazione di una piattaforma dedicata, ormai non più appannaggio di esperti, le potenzialità offerte dallo studio si trasformano in uno strumento delle molteplici possibilità. I modelli, in passato visualizzabili solo attraverso costosi strumenti dedicati, oggi trovano nuove forme di accesso mediante applicazione che come in questo caso risultano semplificate e realizzabili senza conoscenza informatiche specifiche. Questo approccio può aprire la strada a forme di catalogazione digitale articolate e strutturate che sfruttano la velocità della rete, anche di dispositivi mobili, per rendere accessibili un numero notevole di informazioni a diverse tipologie di utenza. Inoltre, la possibilità di appoggiarsi a repository in cloud per il contenimento dei dati può essere uno strumento utilizzabile anche ai fini della ricerca: ciascun modello discretizzato e garantito nella sua qualità metrica dal realizzatore, diviene un nuovo modo di affrontare non solo l'approccio al manufatto ma anche strumento interattivo per la ricerca. II tutto facendo uso della medesima base dati che, proprio in virtù della sua natura digitale, può costituirsi anche come riferimento solido e referenziato da approfondire e integrare verso una visione più aperta e partecipata della cultura. 
Fig. 9. App: funzioni per la creazione di sezioni e misurazione dei modelli $3 d$

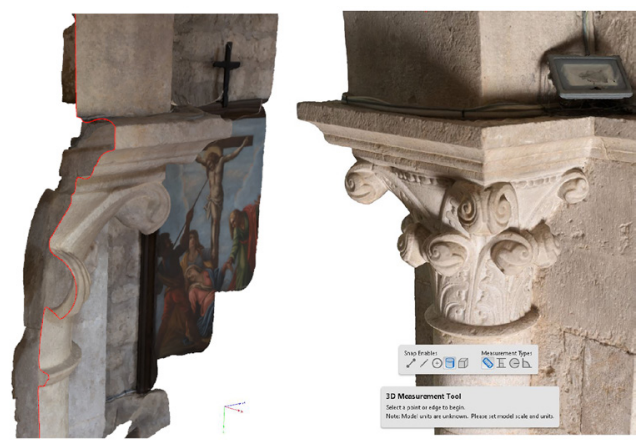

Note

[I] Si è utilizzato un 3d laser scanner FARO.

[2] Camera Canon 600d Mark II, Dati di scatto: formato file Raw; bilanciamento del bianco automatico; Obiettivo 50 mm posto ad una distanza massima dall'oggetto di circa I/ I,5 metri; Sensibilità ISO I00 (nativo) - 200 (in relazione alle condizion di luce presenti); Diaframma fl I- 16 (in relazione alle condizioni di luce presenti); Tempi di scatto mai superiori a 2,5 secondi (in relazione alle condizioni di luce presenti).

\section{Riferimenti bibliografici}

Bianchini Carlo, Inglese Carlo, Ippolito Alfonso (2016). I Teatri del Mediterraneo come esperienza di rilevamento integrato. The Theaters of the Mediterranean as integrated survey experience. Roma: Sapienza Università editrice.

Baglioni Leonardo, Inglese Carlo (2015) II rilievo integrato come metodo di studio: il caso di San Bernardino ad Urbino. In Disegnare. Idee Immagini, 34-45, 5 I.

Bianchini Carlo (2007), Dal reale al virtuale (e ritorno): il modello ligneo di Antonio da Sangallo per il nuovo San Pietro in Vaticano. In Disegnare Idee Immagini, 36-49, 34.

Bianchini Carlo, Ippolito Alfonso, Senatore Luca J. (2019). The Wooden Models of the Vatican Basilica by Antonio da Sangallo and Michelangelo: Survey, Modelling and Interpretation. In: Fabio Bianconi, Marco Filippucci (eds.). Digital Wood Design. Innovative Techniques of Representation in Architectural Design. Springer International Publishing AG 20 I 9, pp. 32 I-342.

Centofanti Mario, Brusaporci Stefano, Lucchese Vittorio (2012). Architectural Heritage and 3D Models. In Di Giamberardino Paolo, lacoviello Daniela, Jorge Renato Natal, Tavares João Manuel (a cura di). Computational Modeling of Objects Presented in Images. Foundamentals, Methods and Applications. London:Taylor \& Francis Group, pp.3 I-49.

Gallotta E. (2020). L'architecture du XIlle siècle dans le Latium méridional: tradition et innovation aux origines d'un gothique régional, in Sandron Dany, Ceccotti Camilla, Gallotta Emanuele (a cura di). L'Architecture gothique entre réception et invention (Xlle-XXe siècles). Atti della giornata di studi. Parigi, 10 marzo 20 I8, Bruxelles 2020, pp. 45-68.

Ippolito Alfonso, Senatore Luca J., Belelli Marchesini Barbara, Ceroli Gabriella (20I5). From Survey to Representation of the Model. A Documentation of Typological and Chronological Sequences of Archaeological Artefacts: Traditional and Innovative Approach. In CAA 2014 Proceedings of the 42nd Annual Conference on Computer Applications and Quantitative Methods in Archaeology. Oxford: Archaeopress, pp 107-114.

Manferdini Anna Maria, Russo Michele (20/3). Multi-scalar 3D digitization of Cultural Heritage using a low-cost integrated approach. In 2013 Digital Heritage International Congress. Marseille, pp. I53-I60.

Saygi Gamze, Remondino Fabio (20I3). Management of Architectural Heritage Information in BIM and GIS: State-of-the-art and Future Perspectives. In International Journal of Heritage in the Digital Era. Vol. 2(4), pp. 695-7I3.

Senatore Luca J. (20I2). La scala dei modelli. In Carlo Bianchini (a cura di). Documentation of Mediterranean Ancient Theatres: Athena's activities in Merida. Roma: Gangemi Editore, pp. I43- 144.

Villa, G. (2016). La misura urbanistica dell'antico nella Roma medicea. In Sandron Dany. Le passé dans la ville. Paris: Press de I'Université Paris-Sorbonne, pp. |69-191.

$<$ https://appinventor.mit.edu/>.

\section{Autori}

Carlo Inglese, Sapienza Università di Roma, carlo.inglese@uniromal.it

Emanuele Gallotta, Sapienza Università di Roma, emanuele.gallotta@uniromal.it

Luca James Senatore, Sapienza Università di Roma, luca.senatore@uniromal .it

Guglielmo Villa, Sapienza Università di Roma, guglielmo.villa@uniromal.it .

Per citare questo capitolo: Inglese Carlo, Gallotta Emanuele, Senatore Luca James,Villa Guglielmo (2020) Operazioni di acquisizione massiva su componenti di matrice transalpina nell'architettura duecentesca del basso Lazio/Massive survey of transalpine matrix components in the I 3th century architecture of Southern Lazio. In Arena A. Arena M. Brandolino R. G., Colistra D., Ginex G., Mediati D., Nucifora S., Raffa P. (a cura di). Connettere. Un disegno per annodare e tessere Atti del $42^{\circ} \mathrm{Con}$. Brano Internozionde dei Docenti delle Discipline dello RoppresentozionelConnecting. Drowng for 


\title{
Massive Survey of Transalpine Matrix Components in the 13th Century Architecture of Southern Lazio
}

\author{
Carlo Inglese \\ Emanuele Gallotta \\ Luca James Senatore \\ Guglielmo Villa
}

\section{Abstract}

The thirteenth century is in many ways the century in which Rome regained a prominent role on the European political chessboard and consequently became again a cultural pole of first magnitude. The phenomenon immediately reverberated also in the regional context of reference, investing the territories that made up the Patrimonium Sancti Petri. The effects did not take long to manifest themselves also in the development of artistic production, thanks to the availability of culturally qualified commissions, which attracted the most prominent artists on the Italian scene, welcoming significant innovations with respect to local tradition. Particularly significant in this context is the diffusion of structural and linguistic models of French origin, borrowed directly from examples from beyond the Alps or from the most advanced experience gained in central Italy.

In this perspective, this contribution aims at creating a repertoire of architectural elements of transalpine derivation, which constitute the vocabulary of the thirteenth-century architectural language in the territory south of Rome.
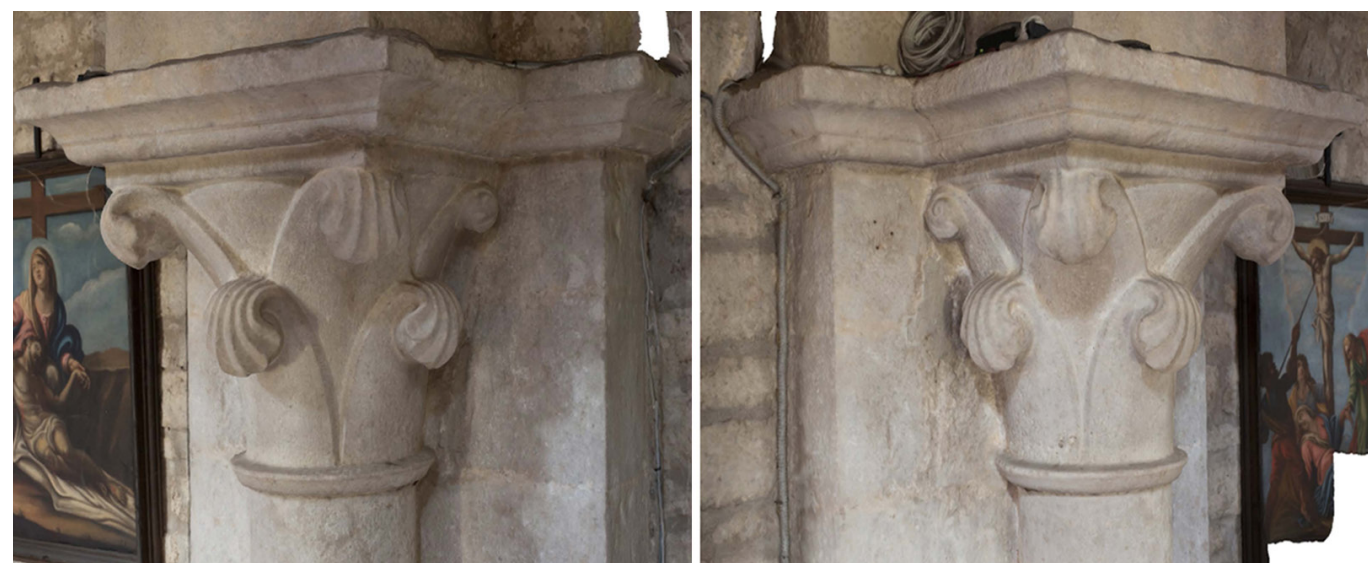


\section{Introduction}

The thirteenth century is in many ways the century in which Rome regained a prominent role on the European political chessboard and consequently became again a cultural pole of first magnitude. Particularly significant in this context is the diffusion of structural and linguistic models of French derivation, borrowed directly from transalpine examples or from the most advanced experience gained in central Italy.

A central theme in the historiography of thirteenth-century Italian architecture is the study of the architecture of religious orders and factories, often of considerable size, such as the abbeys of Fossanova and Casamari, with a new way of conceiving architecture in terms of space, structure and decoration that spread rapidly on a territorial scale, in cities such as Anagni, Alatri and Ferentino.

It is in this perspective that this contribution aimed at creating a repertoire of architectural elements of transalpine derivation, which constitute the vocabulary of the thirteenth-century architectural language in the territory south of Rome.

The direct investigation of the factories has been aimed at clarifying the construction phases, from which relevant data are expected also for their critical reading, but also to investigate aspects more closely related to the construction (techniques, materials, processing and installation methods) useful to frame the construction in a broader framework of material culture and to assess any contributions of workers outside the local context.

Particularly important are the direct surveys of buildings, in some cases little known or completely new from a scientific point of view. Surveys, autopsy observations and stratigraphic readings of the elevations have allowed a deeper understanding of the chronology of the factories, often very articulated during the construction phases. Comparisons, on the other hand, make it possible to establish more solid and precise temporal strongholds for the development of architecture in the area of reference.

With these assumptions, some very particular case studies have been identified from the point of view of the formal characteristics of the decorative elements, Gothic capitals with elaborate solutions, or particularly important in the architectural panorama of the period studied. The Abbey of Fossanova, one of the most important examples of Cistercian architecture in Italy, whose construction, begun in the 1970s of the I2th century, continued well beyond consecration ( 1208 ); the church of Santa Maria Maggiore in Ferentino, dating back to the second half of the I3th century; finally, the collegiate church of Santa Maria Assunta in Amaseno, consecrated in 1 177, whose current facies can be dated to the first decades of the I3th century.

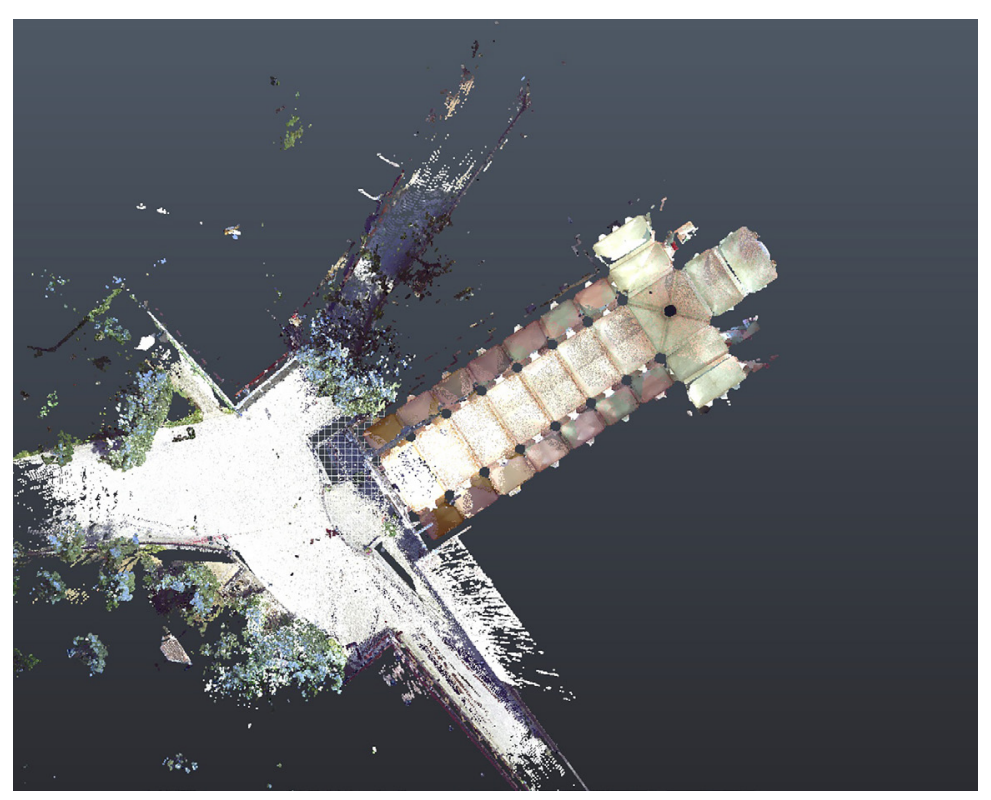




\section{Research objectives}

The research has two closely related objectives: on the one hand, the representation, cataloguing and comparison of architectural and decorative elements, focusing in particular on plastic decoration components (capitals, frames, portals, windows, etc.) aimed at identifying the historical relationships between the transalpine culture and the Italian experience; on the other hand, the creation of an interactive platform aimed at disseminating the results of the study, aimed at an audience of technicians and non-experts.

These objectives find in the moment of the survey a key phase able to respond in an organic way to both requests, offering data able to be studied and made available through operations of consolidated scientific value.

\section{The survey}

The survey was carried out considering the two objectives of the study, the first of a critical historical nature and the second of a divulgation nature. For this reason, the integrated survey procedures were carried out with attention to the quality of the data and their subsequent use.

Specifically, for the study of the artefacts, a 3D laser scanner survey was integrated (fig. I), able to return the overall morphology of the churches studied with an excellent level of detail, with Structure from Motion (Digital Photogrammetry) methodologies for decorative devices and architectural orders.

The survey, therefore, was conducted by integrating data from massive acquisitions from $3 d$ laser scanners for the general parts with SFM photographs, the latter dedicated to all those areas at high altitude, difficult to reach if not with expensive and not immediate provisional works (fig. 2).
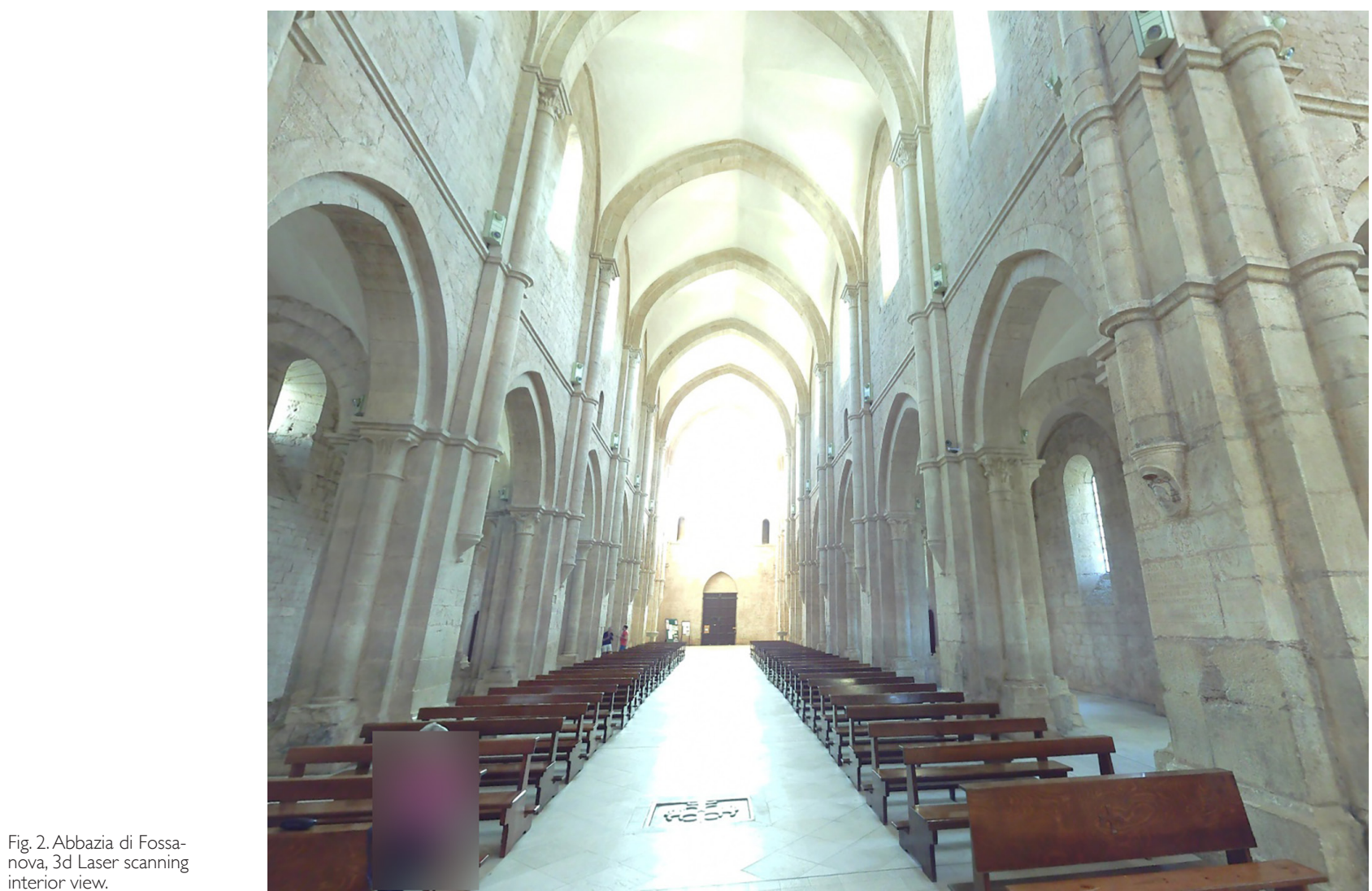
The photographic shots were carried out with the aid of a telescopic rod at the top of which was placed the remotely controlled digital camera for the control of shooting and exposure times. The camera, used as a data acquisition tool, allows a remarkable versatility in the organization of the survey campaign, allowing, among other things, the division of the various architectural elements into different photographic sets. Each photographic set, in turn, has been structured considering the natural lighting present or foreseeing a dedicated lighting system and setting the optimal photographic shooting mode from time to time.

The data (xyz and rgb) thus acquired were processed in dedicated software producing digital mathematical models that were subsequently transformed and modelled into critical works dedicated to the study of the individual components of the artefact. As far as the decorative elements in particular are concerned, particular attention was paid to the creation of mesh models obtained from a point cloud which, once textured using the colour data of the photographic images, provided an excellent data base for the historical stylistic reading of the components.

The restitution of the works involved an interdisciplinary team, the work is currently in progress and the first phase involved the production of 2D models of the main architectural elements: starting from the 3D point cloud, characteristic horizontal and vertical sections have been identified. The scientific standards in the architectural field are deeply linked to the use of 2D models as a critical documentation tool and as an information collector; to this end, the creation of a catalogue containing $3 \mathrm{D}$ and $2 \mathrm{D}$ models of the architectural elements surveyed would allow not only their active cataloguing, i.e. that can be investigated and questioned, but also a comparative study through the reading of repetitive or unique compositional elements.

\section{The case of the capitals}

Each analyzed capital was photographed by positioning the camera at different heights with a variable number of shots between 30 (for the pilasters) and 60 (for the capitals) (fig. 3). An overview of all the objects analyzed was taken and then more attention was paid to the capitals with dedicated photographs ensuring coverage of all surfaces. During processing, the images were processed with dedicated post-production software. Each file has been developed considering the lens used (with application of the relative deformities and standard corrections) and has been converted into JPG format to be transferred within the

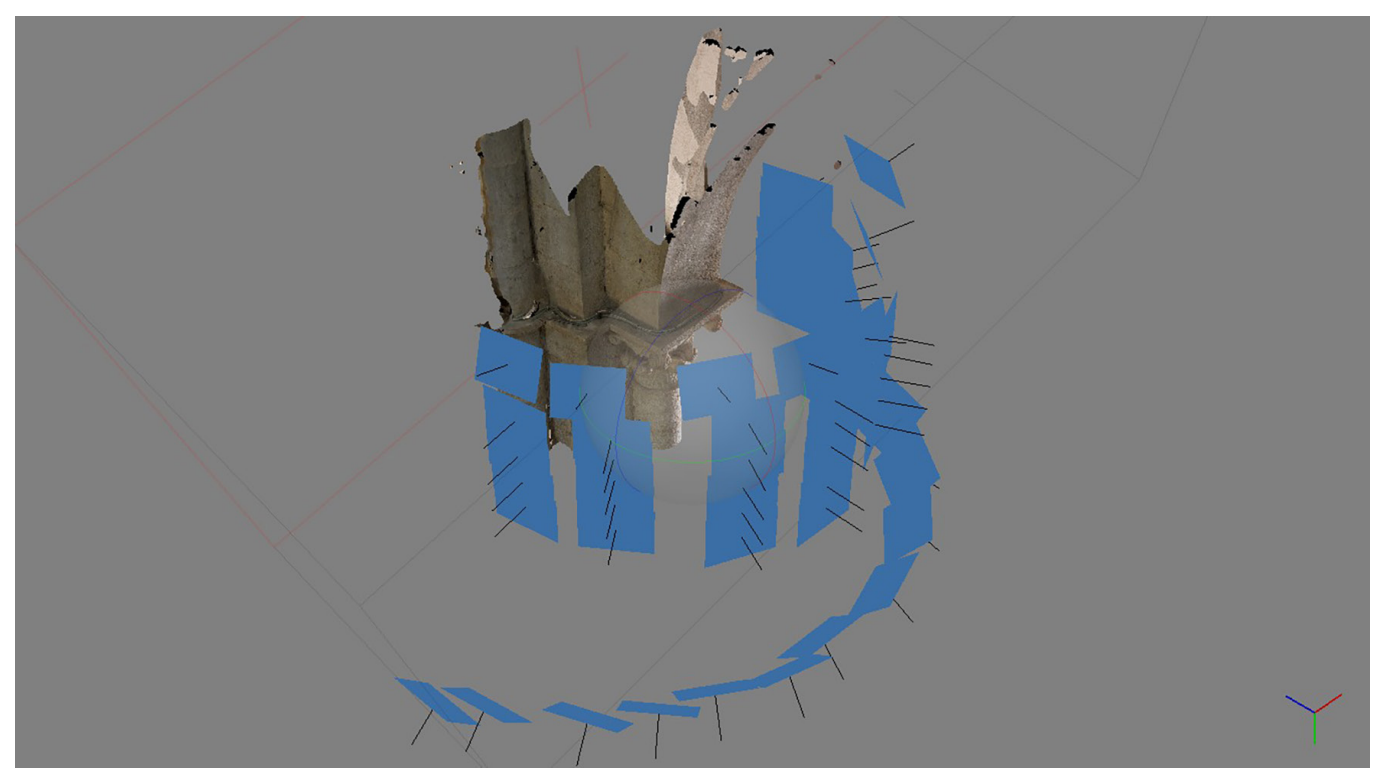


software dedicated to Sfm. The software for Sfm used (Photoscan) processed the images by identifying the relative position of the camera, generated the scattered cloud and then the dense one which was transformed into mesh and then textured.

As far as the measurement is concerned, metric references obtained in situ on remarkable points were used and after the creation of the model, this was scaled to ensure models with an uncertainty scale of I:20 (fig. 4).

Once the model was created, it was cleaned and saved in 3D PDF format to be easily viewable inside any fixed or mobile device and placed in an online repository in order to make the information accessible also remotely using a standard internet connection.

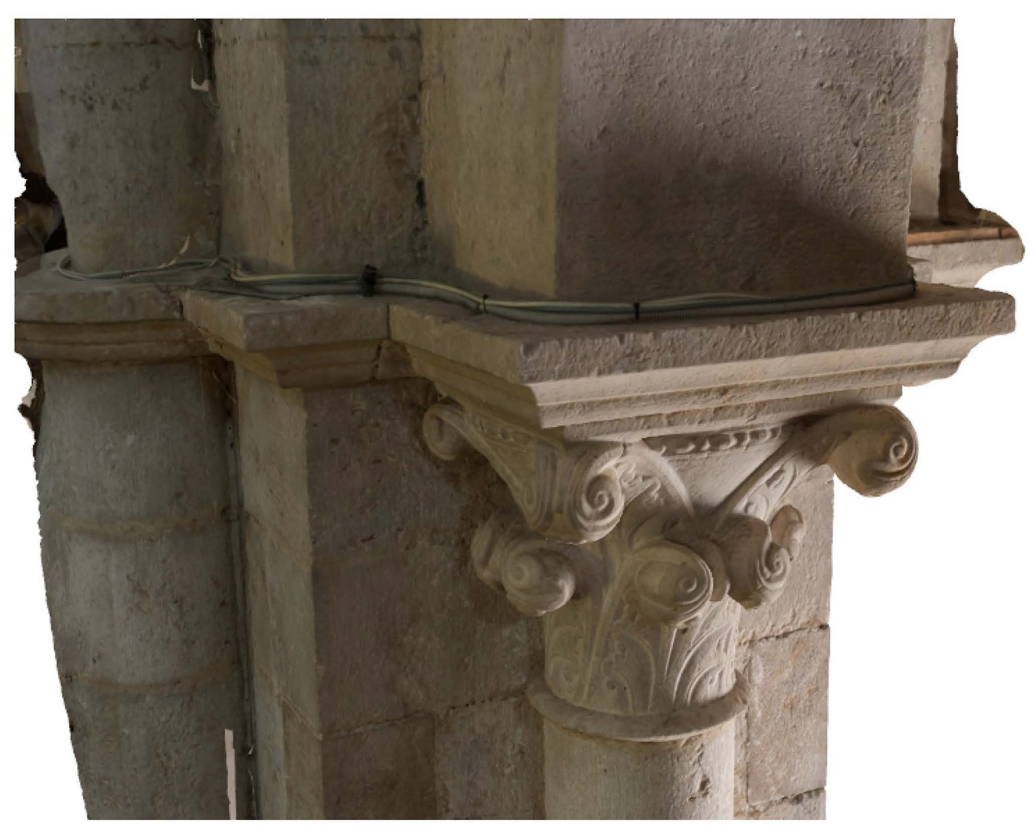

\section{The creation of a digital catalogue}

Using the models created for the historical/critical study, it has been possible to prepare an interactive digital catalogue describing the entire artefact and its characterizing portions. In particular, the Sfm modelling and the creation of models able to describe with a good level of detail the geometrical surfaces of the artefact allowed the experimentation of a new model of valorization of the cultural heritage, which focused in particular on the decorative components of the Abbey.

At the same time, the procedure used has allowed, with a fair speed in the acquisition phase, the achievement of portions of the artefact that otherwise could not have been obtained, ensuring a higher quality of information that can be viewed using the platform.

To manage the data, a prototype App was created using an open source engine offered by the Mit.edu platform. Using the application prepared for the occasion, the catalog allows a good level of interaction between the object and its digital counterpart, and through some dedicated pages the user can navigate the object both in its descriptive components and in the critical historical ones through the vision of dedicated pages or links to external web pages. However, a considerable advantage of this method of dissemination is to be found for what concerns the formal geometrical question of the whole and the parts. Through modules dedicated to the visualization of digital files (external or internal to the application) the data obtained during the acquisition and modeling phases can be easily navigated using 
the usual smart tools, tablets and phones first of all, offering the user new possibilities in terms of knowledge and interaction with the object studied.

Moreover, always using dedicated digital tools, the information, which was traditionally presented to the user in a static way (text and photography), can now be navigated and interrogated in an interactive way with simple steps that allow a personalized level of detail on a single geometrically correct database.

By means of an interactive navigator, each user, both in situ and remotely, has the possibility to deepen the knowledge of the object studied with the activation of a series of thematic cards able to return a series of general and detailed information. Through the use of the same application the user is able to select the main points of interest and have not only a precise and historically reliable description, but, thanks to the integration of the data obtained from the survey and modeling, the user is able to view on the monitor of his mobile phone / tablet, the 3d models.

\section{The app}

The application used for the visualization of the thematic sheets and 3D models consists of an opensource product designed and built for the specific needs of visualization and exploration of the data obtained from the study, whether they are obtained directly from the survey or data processing.

After a first introductory page (fig. 5), the application places the study objects inside an interactive map able to lead the user to the study site (fig. 6). Once on the site, the user can query the application in relation to the general characteristics of the work with links dedicated to pages specifically designed and descriptive of the critical historical characteristics of the object. At the same time the application can provide interactive links with web resources and with sites containing articles or research products dedicated to the work (fig. 7).

Wanting to view the artefact in an interactive way, the user is offered an interface that leads to a series of point cloud viewers and models in PDF 3d format dedicated to the portions of detail (fig. 8). The navigation is guaranteed by a key plan where the points of interest are brought to the user, which once identified allow the loading of data related to individual mo-
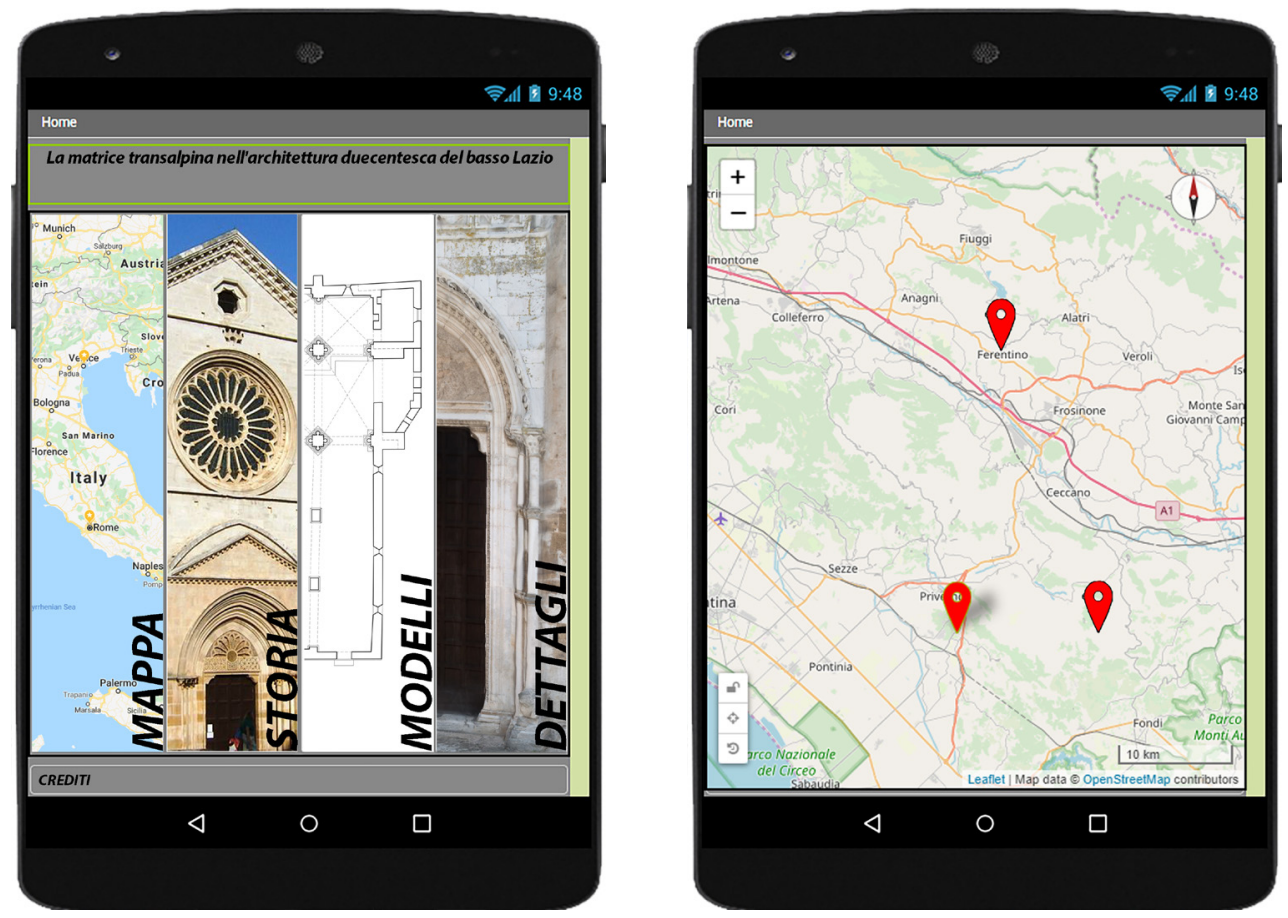
dels and their exploration. Further tools are being developed and aimed at the multi-level verification of the data obtained from the survey: by superimposing data digitally, it is possible to obtain different visions of the same model that represent and identify it in various ways (simplified geometric, textured, false colors etc.) with which the user can interact to obtain different types of information (fig. 9).
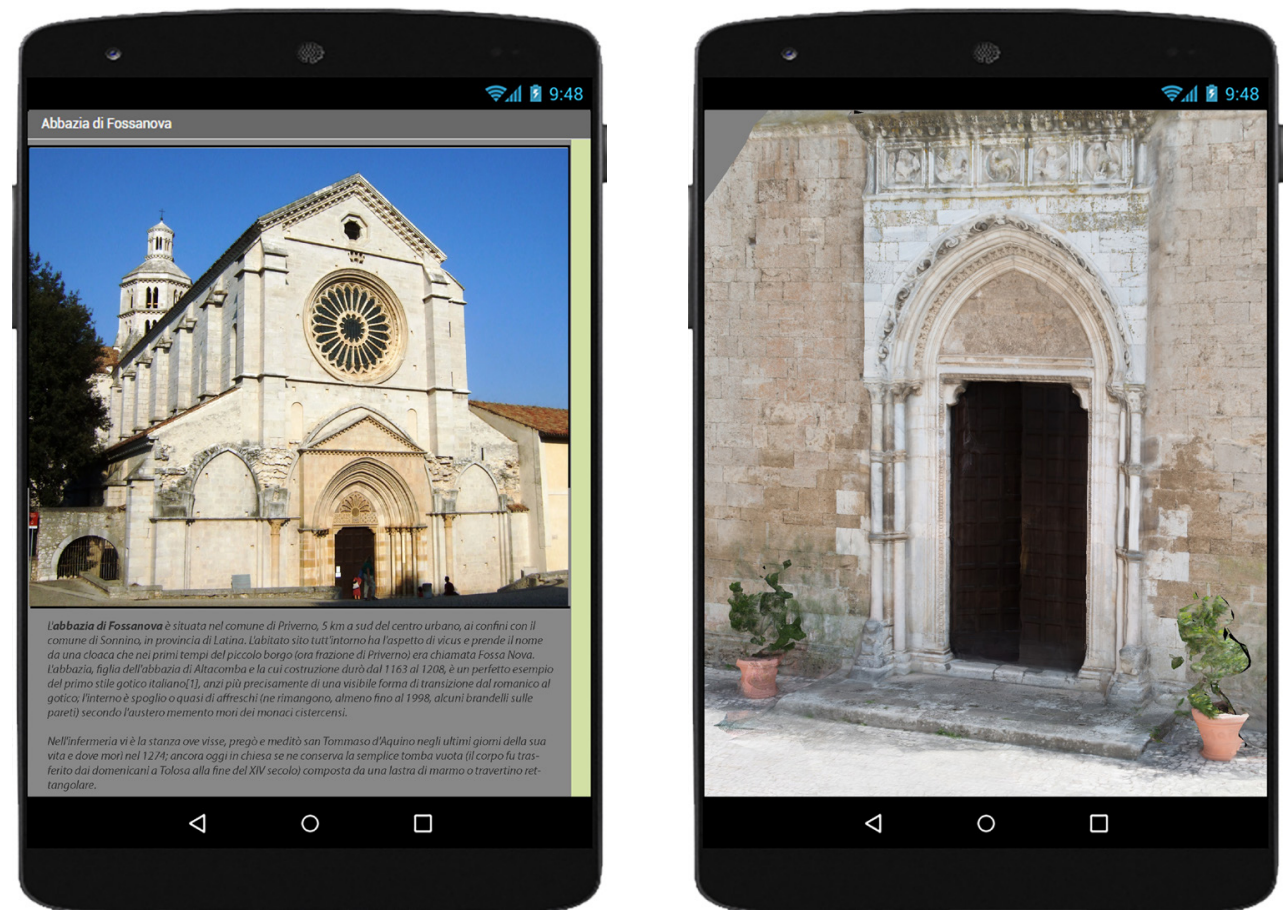

\section{Conclusions}

The study model proposed here, while guaranteeing the scientific quality of the data, represents a significant step forward in the dissemination of architectural heritage, making use of tools now in common use.

Through the creation of a dedicated platform, no longer the prerogative of experts, the potential offered by the study is transformed into an instrument of multiple possibilities. The models, which in the past were only viewable through expensive dedicated tools, now find new forms of access through applications that, as in this case, are simplified and feasible without specific computer knowledge. This approach can pave the way for articulated and structured forms of digital cataloguing that exploit the speed of the network, including mobile devices, to make a considerable amount of information accessible to different types of users. In addition, the possibility of relying on cloud repositories for data containment can be a tool that can also be used for research purposes: each model discretized and guaranteed in its metric quality by the creator, becomes a new way of approaching not only the object but also interactive tools for research. All this using the same data base that, precisely because of its digital nature, can also constitute a solid and referenced base to be deepened and integrated towards a more open and participatory vision of culture. 


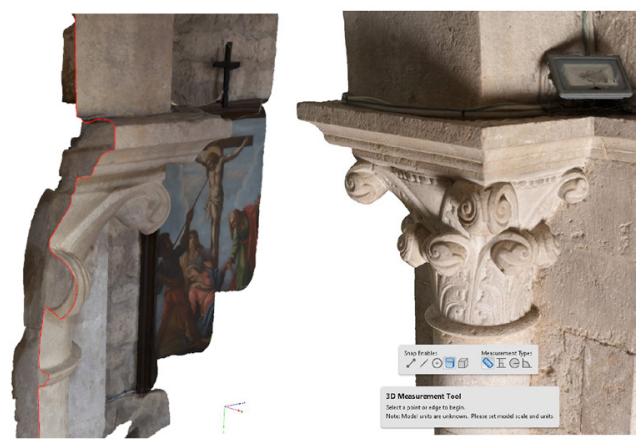

\section{Notes}

[I] All Lidar surveying operations were carried out with Scanner Faro.

[2] Canon 600d Mark II Camera, Shooting Data: Raw File Format; Auto White Balance; 50mm lens placed at a maximum distance from the object of about I/I.5 meters; ISO I00 sensitivity (native) - 200 (depending on lighting conditions); FI I I 6 aperture (depending on lighting conditions); Shooting time never longer than 2,5 seconds (depending on lighting conditions).

\section{References}

Bianchini Carlo, Inglese Carlo, Ippolito Alfonso (2016). I Teatri del Mediterraneo come esperienza di rilevamento integrato. The Theaters of the Mediterranean as integrated survey experience. Roma: Sapienza Università editrice.

Baglioni Leonardo, Inglese Carlo (2015) II rilievo integrato come metodo di studio: il caso di San Bernardino ad Urbino. In Disegnare. Idee Immagini, 34-45, 51 .

Bianchini Carlo (2007), Dal reale al virtuale (e ritorno): il modello ligneo di Antonio da Sangallo per il nuovo San Pietro in Vaticano. In Disegnare Idee Immagini, pp. 36-49, 34.

Bianchini Carlo, Ippolito Alfonso, Senatore Luca J. (2019). The Wooden Models of the Vatican Basilica by Antonio da Sangallo and Michelangelo: Survey, Modelling and Interpretation. In: Fabio Bianconi, Marco Filippucci (eds.). Digital Wood Design. Innovative Techniques of Representation in Architectural Design. Springer International Publishing AG 20 I9, pp. 32 I-342.

Centofanti Mario, Brusaporci Stefano, Lucchese Vittorio (2012). Architectural Heritage and 3D Models. In Di Giamberardino Paolo, lacoviello Daniela, Jorge Renato Natal, Tavares João Manuel (a cura di). Computational Modeling of Objects Presented in Images. Foundamentals, Methods and Applications. London:Taylor \& Francis Group, pp. 31 -49.

Gallotta Emanuele (2020). L'architecture du XIlle siècle dans le Latium méridional: tradition et innovation aux origines d'un gothique régional, in Sandron Dany, Ceccotti Camilla, Gallotta Emanuele (a cura di). L'Architecture gothique entre réception et invention (Xlle-XXe siècles). Atti della giornata di studi (Parigi, 10 marzo 20 I 8), Bruxelles 2020, pp. 45-68

Ippolito Alfonso, Senatore Luca J., Belelli Marchesini Barbara, Ceroli Gabriella (20I5). From Survey to Representation of the Model. A Documentation of Typological and Chronological Sequences of Archaeological Artefacts: Traditional and Innovative Approach. In CAA 2014 Proceedings of the 42nd Annual Conference on Computer Applications and Quantitative Methods in Archaeology. Oxford: Archaeopress, pp 107-114.

Manferdini Anna Maria, Russo Michele (2013). Multi-scalar 3D digitization of Cultural Heritage using a low-cost integrated approach. In 2013 Digital Heritage International Congress. Marseille, pp. I53-160.

Saygi Gamze, Remondino Fabio (20/3). Management of Architectural Heritage Information in BIM and GIS: State-of-the-art and Future Perspectives. In International Journal of Heritage in the Digital Era. Vol. 2(4), pp. 695-7I 3.

Senatore Luca J. (20I2). La scala dei modelli. In Carlo Bianchini (a cura di). Documentation of Mediterranean Ancient Theatres: Athena's activities in Merida. Roma: Gangemi Editore, pp. I43-I44.

Villa, G. (2016). La misura urbanistica dell'antico nella Roma medicea. In Sandron Dany. Le passé dans la ville. Paris: Press de I'Université Paris-Sorbonne, pp. |69-191.

$<$ https://appinventor.mit.edu/>.

\section{Authors}

Carlo Inglese, Sapienza Università di Roma, carlo.inglese@uniromal.it

Emanuele Gallotta, Sapienza Università di Roma, emanuele.gallotta@uniromal.it

Luca James Senatore, Sapienza Università di Roma, luca.senatore@uniromal .it

Guglielmo Villa, Sapienza Università di Roma, guglielmo.villa@uniromal.it

To cite this chapter. Inglese Carlo, Gallotta Emanuela, Senatore Luca James, Villa Guglielmo (2020) Operazioni di acquisizione massiva su componenti di matrice transalpina nell'architettura duecentesca del basso Lazio/Massive survey of transalpine matrix components in the I3th century architecture of lower Lazio. In Arena A., Arena M., Brandolino R.G., Colistra D., Ginex G., Mediati D., Nucifora S., Raffa P. (a cura di). Connettere. Un disegno per annodare e tessere. Atti del $42^{\circ}$ Convegno Internazionale dei Docenti delle Discipline della Rappresentazione/Connecting. Drawing for weaving relationships. Proceedings of the 42th International Conference of Representation Disciplines Teachers. Milano: FrancoAngeli, pp. 23।2-2327. 